\title{
Substrate relations for rillscale [Atriplex suckleyi] on ben- tonite mine spoil
}

\author{
M.E. VOORHEES, D.W. URESK, AND M.J. TRLICA
}

\section{Abstract}

Rillscale (Atriplex suckleyi), the dominant native invader of bentonite mine spoil in northern Wyoming, is apparently uniquely adapted to this extremely harsh plant growth substrate. The objective of this study was to determine which chemical properties of spoil influence growth of rillscale. Plant production, foliar and spoil chemistry on spoils were treated as a factorial arrangement of treatments, each of 3 spoil amendments (gypsum, fertilizer, sawdust). Regression analyses with analysis of covariance and factorial analysis of variance model were used to control for effects of amendments on plant production. Calcium and nitrogen were growth-limiting nutrients for this plant. The species was very sensitive to an increase in the level of spoil molybdenum and in the ratio of copper to molybdenum, but was very tolerant of high levels of soluble sodium. Rillscale acted as a molybdenum accumulator.

\section{Key Words: minerals, reclamation, forage, amendments}

The bentonite clay mining industry ranks high among major land-disturbance operations in the 3-state region of Montana, South Dakota, and Wyoming, where most of the world's sodictype bentonite is found. Bentonite mine spoil is difficult to revegetate because it poses several problems for plant growth including, salinity, sodicity, high percentages of expansive clays, and possible elemental deficiencies and toxicities (Bjugstad et al. 1981).

Atriplex suckleyi (Torrey) Rydb., commonly called rillscale, is a spreading, annual chenopod limited in range to the northern High Plains. It occurs on clayey, saline lands to which few species are adapted (Frankton and Bassett 1970) and is the dominant native invader of bentonite mine spoil (Sieg et al. 1983). Morphology and apparent vigor of the species vary considerably from site to site, and studies have shown that growth and vigor of the species are greatly improved by organic amendments (Smith et al. 1985, Voorhees et al. 1987).

This study was part of a larger project to evaluate suitability of rillscale for use in revegetation of bentonite mine spoil. Other papers from the project have been published elsewhere and describe studies of the effects of amendments on spoil chemistry (Voorhees and Uresk, 1990), infiltration rate (Voorhees 1986), standing crop of rillscale (Voorhees et al. 1987), and foliar chemistry (Voorhees 1990).

\section{Method}

The study was conducted on an area west of the central Black Hills on the Mowry Shale formation, approximately $2 \mathrm{~km}$ northwest of Upton, Wyoming. Sites in this region have been mined at various times during a period of more than 30 years. Elevation at the study area was approximately $1,290 \mathrm{~m}$, and average annual precipitation was about $370 \mathrm{~mm}$ (NOAA 1983). Undisturbed vegetation is characteristically big sagebrush (Artemisia tridentata) grassland interspersed with stands of ponderosa pine (Pinus ponderosa). The area provides forage for livestock and habitat for

\footnotetext{
Research was conducted by USDA Forest Service, Rocky Mountain Forest and Range Experiment Station, South Dakota School of Mines, Rapid City 57701; and Department of Range Science, Colorado State University, Fort Collins 80523

Voorhees is research scientist, and Uresk is supervisory research biologist, USDA Forest Service, Rocky Mountain Forest and Range Exp. Sta.; Trlica is professor, Department of Range Science, Colorado State Univ.

Manuscript accepted 5 May 1990.
}

many species of wildlife.

A topographically uniform area was selected on unreclaimed bentonite mine spoil that had been mined sometime before 1968 . Topography on and around the site insured minimal runoff and runon. Data from the Upton weather station were used as an estimate of precipitation during the study period.

The study site was rototilled to a depth of approximately $5 \mathrm{~cm}$. The experimental design was a $2^{3}$ factorial arrangement of treatments with each of 3 spoil amendments (gypsum, fertilizer, and sawdust with nitrogen) at 2 levels-with and without amendment. This design contained a total of 8 treatments: a control, each of 3 amendments used alone, and all possible combinations of the 3 amendments. The 8 treatments were replicated twice to give a total of 16 plots, $60 \mathrm{~cm} \times 150 \mathrm{~cm}$ each.

The gypsum amendment $\left(\mathrm{CaSO}_{4}\right)$ was applied at the rate of 31 $\mathrm{Mg} \mathrm{ha}^{-1}$. The fertilizer amendment added nitrogen $(\mathrm{N})$, phosphorus ( $P$ ), and potassium (K) at rates of $114 \mathrm{~kg}, 23 \mathrm{~kg}$, and $50 \mathrm{~kg}$ per hectare, respectively. This $P$ and $K$ fertilization rate was considered to be moderate for dryland soils that support rapidly growing forbs. The nitrogen rate was high because of low spoil organic matter and nitrogen. Nitrogen and phosphorus were added as ammonium nitrate $\left(\mathrm{NH}_{4} \mathrm{NO}_{3}\right)$ and diammonium phosphate $\left(\mathrm{NH}_{4}\right)_{2} \mathrm{HPO}_{4}$ ) and potassium chloride ( $\mathrm{KClal}$ ).

The third amendment was sawdust with nitrogen, added at the ratio of 1 part sawdust to 2 parts spoil (by volume) to the 5 -cm spoil depth. Depth of tillage was limited so that use of heavy equipment could be avoided, and thus efficacy of much less expensive treatments could be evaluated. Use of heavy equipment is prohibitively expensive in reclamation of these spoils on an experimental basis. Inorganic nitrogen $\left(\mathrm{NH}_{4} \mathrm{NO}_{3}\right.$ ) corresponding to $0.6 \%$ of sawdust by weight ( $6 \mathrm{~kg} \mathrm{~N} \mathrm{Mg}^{-1}$ sawdust) was added to the sawdust before its application to prevent a large increase in the carbon-to-nitrogen ratio and subsequent tie-up of spoil nitrogen by microorganisms (Allison 1965).

Introduction of calcium ions $\left(\mathrm{Ca}^{++}\right)$in the form of $\mathrm{CaSO}_{4}$ was intended to facilitate exchange with monovalent sodium, to encourage flocculation and water penetration (Brady 1974), and to discourage surface crust formation. The sawdust amendment was intended to increase permeability. Organic matter additions greatly increase the stability of the substrate where organic matter is less than 2\% (Marshall and Holmes 1979) as in bentonite mine spoil (Uresk and Yamamoto 1986).

Gypsum and sawdust amendments were manually incorporated into tilled spoil, whereas the fertilizer was surface-broadcast. Plots were tilled, amended, and seeded in April 1982 and sampled for 2 growing seasons. The seed had been obtained from sites along the Montana-Wyoming border during late summer of 1980. Each plot was seeded at the rate of 3 live seeds per $\mathrm{cm}^{2}$. Seeds were surfacebroadcast and raked into the spoil.

Estimates of aboveground biomass (production) for rillscale were obtained by harvesting different halves of each plot at estimated peak in standing crop for 2 consecutive years. All harvested biomass was oven-dried at $55^{\circ} \mathrm{C}$, weighed, ground to pass through a 20-mesh screen, and stored for chemical analysis. Biomass samples were not washed to remove surface contamination: therefore, elemental analysis of these samples represents what herbivores would ingest. Spoil samples were collected at a depth of $0-10 \mathrm{~cm}$ immediately after the biomass harvest, air-dried, and stored for chemical analysis. This sampling depth was selected to characterize 
the observed rooting zone of rillscale.

\section{Spoil and Foliage Analysis}

Determinations of concentrations of elements in spoil (As, B, $\mathrm{Cd}, \mathrm{Cu}, \mathrm{Fe}, \mathrm{Pb}, \mathrm{Mn}, \mathrm{Mo}, \mathrm{Ni}, \mathrm{P}, \mathrm{K}, \mathrm{Se}, \mathrm{Na}$, and $\mathrm{Zn}$ ) were made on an ammonium bicarbonate-diethylenetriaminepentaacetic acid (AB-DTPA) extract (Soltanpour and Schwab 1977) using inductively coupled plasma atomic emission spectrometry (ICP-AES) (Jones 1977).

Saturated paste extracts were difficult to prepare because of the extremely high and variable saturation percentage of spoil. Therefore, the sodium adsorption ratio (SAR) of a 1:5 spoil:water extract was measured using ICP-AES. Electrical conductivities (EC's) and levels of soluble $\mathrm{Ca}, \mathrm{Mg}$, and $\mathrm{Na}$ were also measured on the $1: 5$ extracts.

Sulfate content of spoil was measured using a turbidimetric method (Rhoades 1982a). Nitrogen percentages were estimated using the salicylic acid modification of the semimicro-Kjeldahl method to include nitrates (Bremner and Mulvaney 1982). The pH was measured on a 1:5 spoil extract. Cation exchange capacity (CEC) was determined using the sodium acetate method (Rhoades 1982b).

Plant tissue analyses included total nitrogen by conventional micro-Kjeldahl (Church and Pond 1978) and elemental concentrations of nitric acid-extractable, $\mathrm{Al}, \mathrm{As}, \mathrm{Ba}, \mathrm{B}, \mathrm{Cd}, \mathrm{Ca}, \mathrm{Cr}, \mathrm{Cu}, \mathrm{Fe}$, $\mathrm{Mg}, \mathrm{Mn}, \mathrm{Mo}, \mathrm{Ni}, \mathrm{P}, \mathrm{K}, \mathrm{Se}, \mathrm{Na}, \mathrm{Sr}, \mathrm{Ti}$, and $\mathrm{Zn}$. Elemental concentrations of nitric acid extracts were measured using ICP-AES on the nitric digest (Gestring and Soltanpour 1984, Havlin and Soltanpour 1980). The ICP-AES method operates at temperatures between 5700 and $9700^{\circ} \mathrm{C}$ (Fassel and Knisely 1974), and organic molecules or complexes in solution would be effectively atomized (Havlin and Soltanpour 1980).

\section{Statistical Analysis}

An element or property was considered limiting to growth if it met these 2 criteria (Bannister 1976): (1) a positive correlation between concentrations of the element in spoil and production estimates, and (2) a positive correlation between concentrations of the element in foliage and concentrations of the element in spoil. Spoil properties that could not be measured in foliage (EC, CEC, $\mathrm{pH}$, saturation percentage, $\mathrm{SAR}$ ) were subjected to the first criterion only.

The 2 criteria were individually examined using 2 separate regression analyses on 16 data points. The first regression analysis determined the strength and significance of the correlation between production of rillscale and each spoil characteristic, after treatment effects associated with a full factorial analysis of variance model had been entered into the equation as dummy variables. Terms for each of the 3 spoil amendments and all associated interactions (see $2^{3}$ factoral design) were included in the analysis of variance model. Entering the analysis of variance model terms first allowed the analysis to focus on the relationships between production and spoil characteristics after linear correlations between production and spoil amendments had first been removed (i.e., focus on the partial correlation between production and spoil characteristics adjusting for spoil amendments and their interactions). Partial correlation plots of production against each spoil characteristic were examined to detect any nonlinear relationships. No nonlinear trends were observed.

This study was exploratory work on bentonite spoils. Therefore, the omission of possibly significant relationships between spoil and vegetative parameters was considered more detrimental than possible misclassification of a relationship as significant. To protect against this Type II error, levels of an element in spoil were considered significantly related with production estimates if $p \leq 0.20$ (Hayne 1976, Carmer 1976). This was not meant to indicate a conclusive result, but to point the way to needs of further study.
Table 1. Chemical properties of bentonite mine spoil. The mean and range were computed across controls, all amendments, and amendment combinations.

\begin{tabular}{|c|c|c|c|}
\hline \multirow{2}{*}{$\frac{\text { Property (units) }}{\mathrm{N}(\%)}$} & \multirow{2}{*}{$\frac{\text { Mean }}{0.07}$} & \multicolumn{2}{|c|}{ Range } \\
\hline & & 0.03 & 0.10 \\
\hline$P(\mu g / g)$ & 10.0 & 6.0 & 15.0 \\
\hline $\mathrm{K}(\mu \mathrm{g} / \mathrm{g})$ & 218.0 & 177.0 & -270.0 \\
\hline $\operatorname{Zn}(\mu \mathrm{g} / \mathrm{g})$ & 4.9 & 3.0 & $-\quad 8.0$ \\
\hline $\mathrm{Fe}(\mu \mathrm{g} / \mathrm{g})$ & 35.0 & 11.2 & 84.6 \\
\hline $\operatorname{Mn}(\mu g / g)$ & 16.0 & 8.2 & 33.8 \\
\hline $\mathrm{Cu}(\mu \mathrm{g} / \mathrm{g})$ & 4.2 & 1.8 & 8.3 \\
\hline $\mathrm{Ni}(\mu \mathrm{g} / \mathbf{g})$ & 2.2 & 0.5 & 4.1 \\
\hline $\operatorname{Mo}(\mu \mathrm{g} / \mathrm{g})$ & 0.38 & 0.08 & $-\quad 0.87$ \\
\hline $\mathrm{Na}(\mu \mathrm{g} / \mathrm{g})$ & 5626.0 & 4610.0 & -6620.0 \\
\hline $\mathrm{B}(\mu \mathrm{g} / \mathrm{g})$ & 0.2 & 0.1 & $-\quad 0.3$ \\
\hline Soluble Ca (meq/l) & 7.5 & 0.9 & 23.0 \\
\hline Soluble $\mathrm{Mg}(\mathrm{meq} / \mathrm{l})$ & 2.4 & 0.6 & 8.5 \\
\hline Soluble Na (meq/l) & 37.3 & 18.5 & $-\quad 48.7$ \\
\hline $\mathrm{SO}_{4}(\mu \mathrm{g} / \mathrm{g})$ & 3471.0 & 643.0 & -6000.0 \\
\hline $\mathrm{Pb}(\mu \mathrm{g} / \mathrm{g})$ & 2.2 & 0.9 & $-\quad 4.1$ \\
\hline$C d(\mu g / g)$ & 0.15 & 0.05 & 0.25 \\
\hline As $(\mu g / g)^{1}$ & $<0.2$ & & - \\
\hline $\operatorname{Se}(\mu \mathrm{g} / \mathrm{g})^{1}$ & $<0.2$ & & - \\
\hline $\mathrm{CEC}(\mathrm{meq} / 100 \mathrm{~g})$ & 50.3 & 39.8 & 69.6 \\
\hline pH & 7.4 & 5.9 & 9.0 \\
\hline Saturation percentage & 238.0 & 98.0 & 404.0 \\
\hline $\mathrm{EC}\left(\mathrm{S} \mathrm{m}^{-1}\right)$ & 0.44 & 0.23 & 0.62 \\
\hline SAR & 18.8 & 8.0 & 26.1 \\
\hline
\end{tabular}

'Below detection limits for ICP-AES.

The second regression analysis characterized the relationship between foliage levels and spoil levels of the element, again after treatment effects on foliage levels had been entered into the equation as dummy variables as discussed above. Partial correlation plots of foliage levels of each element against levels of the same element in spoil were examined to detect nonlinear relationships. No nonlinear trends were observed.

\section{Results and Discussion}

\section{Production}

Production of rillscale on amended plots averaged $1,464 \mathrm{~kg}$ dry matter/ ha (range $267-2,913 \mathrm{~kg}$ dry matter/ha). Variability in production occurred as a result of differences in spoil amendments (treatments) (Voorhees et al. 1987) and differences in the properties of unamended spoil.

\section{Spoil Chemistry}

The chemical analysis of spoil at the study site (Table 1) revealed several properties that could be limiting to plant growth. Nitrogen percentages of spoil were low (0.03-0.10\%) as compared with soil nitrogen (4\%) of cool, arid shrublands (Charley 1977). Phosphorus and potassium content of spoil appeared high $(6.0$ to $15.0 \mu \mathrm{g} / \mathrm{g}$ and 177 to $270 \mu \mathrm{g} / \mathrm{g}$, respectively) as compared with similar data for soils of native and improved range grasslands (Soltanpour et al. 1979). The value of phosphorus was comparable to levels in spoils reported by other researchers (Bjugstad et al. 1981, Dollhopf and Bauman 1981, Smith 1984). Zinc, copper, and manganese concentrations appeared sufficient for plant needs (Soltanpour et al. 1979). Spoil iron levels were quite high (Soltanpour et al. 1979). Boron levels were low but not deficient.

The $\mathrm{pH}$ values ranged from slightly acidic to moderately basic and was considered acceptable for most plants (Table 1). In the presence of large amounts of sodium, these $\mathrm{pH}$ levels indicated a high content of neut ral soluble salts (Buol et al. 1980). Because of the high concentration of sulfate salts present, soluble salt content is likely to vary with the soil:water ratio. Therefore, the conductivities of the 1:5 extracts were not used to estimate soil salinity.

The high concentration of sulfates in spoil was a result of the 
Table 2. Chemical properties of foliage of rillscale grown on bentonite mine spoil. The mean and range were computed across controls, all amendments, and amendment combinations.

\begin{tabular}{|c|c|c|c|}
\hline \multirow{3}{*}{$\begin{array}{l}\text { Property (units) } \\
\text { Kjeldahl N (\%) } \\
\text { P (\%) }\end{array}$} & \multirow{2}{*}{$\begin{array}{r}\text { Mean } \\
1.78\end{array}$} & \multicolumn{2}{|c|}{ Range } \\
\hline & & $1.51-$ & 2.18 \\
\hline & 0.18 & 0.14 & 0.22 \\
\hline $\mathrm{K}(\%)$ & 1.11 & 0.94 & 1.30 \\
\hline $\operatorname{Zn}(\mu \mathrm{g} / \mathrm{g})$ & 64.0 & 0.0 & $\begin{array}{l}-\quad 99.0 \\
-\quad 1\end{array}$ \\
\hline $\mathrm{Fe}(\mu \mathrm{g} / \mathrm{g})$ & 9056.0 & 3110.0 & -18600.0 \\
\hline $\operatorname{Mn}(\mu \mathrm{g} / \mathrm{g})$ & 396.0 & 150.0 & -1020.0 \\
\hline $\mathrm{Cu}(\mu \mathrm{g} / \mathrm{g})$ & 6.0 & 4.0 & $-\quad 8.0$ \\
\hline $\mathrm{Ni}(\mu \mathrm{g} / \mathrm{g})$ & 7.0 & 5.0 & 12.0 \\
\hline $\operatorname{Mo}(\mu \mathrm{g} / \mathrm{g})$ & 17.0 & 3.0 & 52.0 \\
\hline $\mathrm{Na}(\%)$ & 8.37 & 7.64 & 9.21 \\
\hline $\mathrm{B}(\mu \mathrm{g} / \mathrm{g})$ & 38.0 & 32.0 & 48.0 \\
\hline $\mathrm{Ca}(\%)$ & 0.45 & 0.37 & 0.54 \\
\hline $\mathrm{Mg}(\%)$ & 0.95 & 0.68 & 1.08 \\
\hline $\mathrm{Al}(\mu \mathrm{g} / \mathrm{g})$ & 1151.0 & 620.0 & -1670.0 \\
\hline $\operatorname{Cr}(\mu \mathrm{g} / \mathrm{g})$ & 4.0 & 3.0 & $\begin{array}{l}-\quad 6.0 \\
\end{array}$ \\
\hline $\mathrm{Ti}(\mu \mathrm{g} / \mathrm{g})$ & 9.0 & 6.0 & 12.0 \\
\hline $\mathrm{Cd}(\mu \mathrm{g} / \mathrm{g})^{1}$ & 1.0 & & - \\
\hline As $(\mu \mathrm{g} / \mathrm{g})^{2}$ & - & & - \\
\hline $\operatorname{Se}(\mu \mathrm{g} / \mathrm{g})^{2}$ & - & & - \\
\hline $\operatorname{Sr}(\mu \mathrm{g} / \mathrm{g})$ & 70.0 & 39.0 & - $\quad 123.0$ \\
\hline $\mathrm{Ba}(\mu \mathrm{g} / \mathrm{g})$ & 34.0 & 12.0 & 58.0 \\
\hline $\mathrm{Cu}: \mathrm{Mo}$ & 0.7 & 0.1 & 2.3 \\
\hline
\end{tabular}

'Below detection limits for ICP-AES.

${ }_{2}$ High iron and aluminum caused severe spectral interferences for arsenic and selenium, making it impossible to determine these elements.

accumulation of salts, especially $\mathrm{Na}_{2} \mathrm{SO}_{4}$ (Mengel and Kirkby 1982 ) or the oxidation of naturally occurring iron, nickel, and copper sulfides, which are common in soils with restricted drainage (Brady 1974) (Table 1). Jarosite, a hydrous potassium iron sulfate that has been shown to be present in bentonite mine spoil (Smith 1984, Smith et al. 1985) accounted for some of the sulfate content.

The CEC of spoil was variable but quite high on the average at 50 $\mathrm{meq} / 100 \mathrm{~g}$, a value intermediate between those that might be expected for montmorillonite and illite clay minerals (Brady 1974) (Table 1). Mineralogical analysis has shown both of these clay types as well as kaolinite to be present in bentonite mine spoil (Uresk and Yamamoto 1986). The saturation percentage of spoil was extremely high.

\section{Foliage Chemistry}

Nitrogen, phosphorus, potassium, zinc, copper, boron, and magnesium in tissue of rillscale were at levels within the range considered normal for most plants (Epstein 1972, Larcher 1980, Mengel and Kirkby 1982). The extremely high iron content of $9,000 \mu \mathrm{g} / \mathrm{g}$ is more than 9 times the normal range for most plants (Larcher 1980) but is probably partially due to presence of spoil on unwashed foliage (Table 2). The concentration of aluminum in foliage was also very high at $1,151 \mu \mathrm{g} / \mathrm{g}$ : the usual amount found in the tissues of higher plants is about $200 \mu \mathrm{g} / \mathrm{g}$ (Mengel and Kirkby 1982). Average manganese levels were near the high end of the normal range $(300 \mu \mathrm{g} / \mathrm{g})$. Levels of nickel, chromium, molybdenum, and sodium were higher than normal but were not considered to be toxic for plants. The copper to molybdenum ratio was low at 0.7 , which could lead to molybdenum induced copper deficiency in cattle and could limit the use of rillscale as forage. Calcium levels in foliage were marginally low (Larcher 1980).

\section{Production and Spoil Chemistry}

Spoil molybdenum was the most significant $(p \leq=0.018)$ spoil parameter for predicting production of rillscale (Table 3). Although concentrations in spoil molybdenum did not appear excessive, high levels of available molybdenum were associated with low growth of rillscale $(r=-0.76)$. Demonstrations of plant yield decrease caused by excessive molybdenum are rare (Murphy and
Table 3. Partial linear correlation coefficients ( $r$ ), probability levels $(p)$, and regression coefficients $(b)$ between $A$ ) production of rillscale grown on bentonite mine spoil and each spoil chemical property, and B) elemental level in foliage of rillscale and spoil level of each element. Correlation coefficients were estimated after adjusting for the effects of treatment. Spoil properties that are not listed were not significantly $(p<0.20)$ related to production of rillscale grown on spoil.

\begin{tabular}{|c|c|c|c|c|c|c|}
\hline \multirow[t]{2}{*}{$\begin{array}{l}\text { Spoil Chemical } \\
\text { Property }\end{array}$} & \multicolumn{3}{|c|}{ Production (A) } & \multicolumn{3}{|c|}{ Foliage concentration (B) } \\
\hline & $r$ & $p$ & $b$ & $r$ & $p$ & $b$ \\
\hline Extractable Mo & -0.76 & $(0.018)$ & -1961.0 & +0.57 & $(0.11)$ & +29.9 \\
\hline Extractable $\mathrm{Ni}$ & +0.69 & $(0.041)$ & +395.6 & -0.30 & $(0.435)$ & -0.5 \\
\hline Soluble Ca & +0.38 & (0.048) & 65.09 & 0.42 & $(0.106)$ & -.002 \\
\hline Extractable $\mathrm{Cd}^{1}$ & +0.67 & $(0.047)$ & +6945.4 & & & \\
\hline $\begin{array}{l}\text { Saturation } \\
\text { percentage }\end{array}$ & -0.67 & (0.048) & -4.5 & & & \\
\hline Extractable $\mathrm{Na}$ & -0.64 & $(0.061)$ & -0.7 & -0.55 & $(0.126)$ & -0.0 \\
\hline $\mathrm{Cu}: \mathrm{Mo}^{2}$ & +0.64 & $(0.06$ & +14.8 & +0.61 & $(0.081)$ & +0.0 \\
\hline Extractable $\mathrm{Cu}$ & +0.63 & $(0.069)$ & +216.5 & -0.18 & $(0.646)$ & -0.7 \\
\hline Extractable $\mathrm{Pb}^{2}$ & -0.61 & $(0.084)$ & -443.9 & & & \\
\hline Extractable K & +0.57 & $(0.110)$ & +25.0 & -0.49 & $(0.183)$ & -0.0 \\
\hline $\mathrm{pH}^{2}$ & -0.54 & $(0.132)$ & -350.7 & & & \\
\hline SAR $^{2}$ & -0.32 & $(0.147)$ & -53.00 & & & \\
\hline Extractable $\mathbf{M g}$ & +0.52 & $(0.156)$ & +49.4 & -0.14 & $(0.717)$ & -4.6 \\
\hline Total N & +0.51 & $(0.156)$ & +18707.8 & +0.34 & $(0.365)$ & +2.8 \\
\hline
\end{tabular}

'Below ICP-AES detection levels in foliage $(1.0 \mu \mathrm{g} / \mathrm{g})$.

${ }^{2}$ Not analyzed for plant tissue.

Walsh 1972). Standing crop decrease with increased spoil molybdenum may have been associated with increased $\mathrm{pH}$. Molybdenum availability is very dependent on and increase with $\mathrm{pH}$ (Brady 1974).

Wood residue amendment has been associated with decreased spoil Mo and with increased standing crop (Voorhees et al. 1987, Voorhees and Uresk 1990). Foliage levels of molybdenum increased as molybdenum levels of spoil increased $(r=0.57)$. This indicated that rillscale was a molybdenum accumulator, which may limit its use as forage on areas with high levels of available molybdenum.

Plant accumulation of molybdenum and the apparent negative effects of molybdenum on growth might be mitigated by the addition of copper to spoil containing high levels of molybdenum (Table 3). Increases in the copper to molybdenum ratio of spoil were associated with increased production $(r=0.64)$ and an increase in the copper to molybdenum ratio of foliage $(r=0.61)$. A decrease in $\mathrm{pH}$ of spoil would increase availability of $\mathrm{Ca}$ and decrease availability of Mo.

Increases in the extractable amounts of several divalent cations $(\mathrm{Ni}, \mathrm{Cd}, \mathrm{Cu}, \mathrm{Mn}$ ) were associated $(p \leq 0.20)$ with increases in yield of rillscale. Increased amounts of potassium in spoil were also associated with increased growth $(p \leq 0.11)$ although potassium levels in spoil were high (Table 1). Foliage concentrations of these elements were generally not correlated with spoil concentrations (cadmium was below ICP-AES detection levels in foliage) (Table 3). Rillscale production was negatively correlated with levels of extractable spoil sodium and spoil saturation percentage. These relations indicate that these bivalent ions were not limiting as nutrients, but reflected improved spoil structure for the benefit of plant growth because of their (1) presence on exchange sites in lieu of sodium, (2) presence in solution as salts, or (3) relationship to increased organic matter content or decreased $\mathrm{pH}$ of spoil.

Although production of rillscale was positively correlated $(p=$ .048) with levels of soluble calcium in spoil $(r=0.38)$, foliage concentrations of calcium were negatively correlated $(p=0.106)$ with levels of soluble calcium (Table 3). Foliage calcium levels in this study were low, and calcium in foliage is generally not affected by levels in the nutrient medium when the calcium supply in the substrate is adequate (Loneragan and Snowball 1969). Therefore 
the decrease in foliage calcium associated with increases in soluble calcium in spoil appeared to be a dilution effect (Larcher 1980, Mengel and Kirkby 1982). The dilution of calcium in plant tissues apparently occurs as a result of increased production caused by greater availability of calcium and by improvement of spoil structure as the amount of exchangeable calcium increases. Increases in the levels of soluble calcium also increase the salt tolerance of plants (La Haye and Epstein 1969). Gypsum amendment has been associated with increases in soluble $\mathrm{Ca}$ in spoil and with increased plant standing crop, when used in combination with an amendment that increased permeability of spoil (Voorhees et al. 1987, Voorhees 1986).

Increases in levels of extractable lead were associated with decreased production of rillscale $(p=0.08)$ although lead content of spoil was not excessive. Wood residue amendment has been associated with a decrease in extractable lead in spoil and with an increase in standing crop (Voorhees et al. 1987, Voorhees and Uresk 1990).

The negative association between production and saturation percent $(r=-0.67)$ reflects differences in growth caused by differential permeability of spoil. A high saturation percentage indicates high water-holding capacity but also indicates limits on hydraulic conductivity, because absorbed water is held near the spoil surface and is not readily available to many plant roots. A high saturation percentage can result in damage to root systems by limiting air flow when the substrate is wet. Differences in the saturation percentage of spoil probably resulted from spatial variability in the proportion of the mixture of shale and bentonite clay in spoil or from degree of saturation of the exchange complex with $\mathrm{Na}$.

Decreases in production were associated with increases in the levels of extractable sodium in spoil $(r=-0.64)$ and with increases in SAR ( $r=-0.32)$ (Table 3). This indicated that sodium was probably detrimental to growth when present on exchange sites. Gypsum amendment has been associated with a decrease in SAR and with an increase in standing crop when used in combination with an amendment that increased permeability of spoil (Vorhees et al. 1987, Voorhees 1986). Extractable sodium was negatively correlated $(r=-0.55)$ with foliar sodium. Therefore, extractable sodium was either not available to plants or uptake of sodium by plants was limited because of its effects on spoil structure.

Plant growth was positively associated with decreases in $\mathrm{pH}(p=$ $0.13)$ and with increases in total nitrogen $(p=0.16)$ (Table 3). This was not surprising when the mean and range of these properties in spoil were considered.

Spoil characteristics were not adjusted for the effect of amendments. The statistical design may have been less sensitive to growth-limiting effects of characteristics that were affected by amendments. Spoil characteristics not found to be growth-limiting in this study and previously shown to be affectd by the amendments used in this study include the sodium adsorption ratio, sulfate, manganese, soluble sodium, phosphorus, potassium, zinc, boron, and cation exchange capacity (Voorhees et al. 1987).

The lack of correlation between rillscale production and spoil levels of some elements, or between foliage levels and spoil levels of some elements, may reflect the inadequacies of the AB-DTPA procedure for evaluating plant-available levels of these elements. Spoil or foliage concentrations were below ICP-AES detection limits for some elements (As, Se, and Cd), and spectral interferences prevented determination of arsenic and selenium in plant tissue. Assessment of the relationships between foliage and spoil concentrations of these elements was, therefore, not possible. In some cases the range in chemical composition of spoil may not have been wide enough for significant differences in plant growth to become evident.

\section{Conclusions}

Calcium was the only nutrient that was deficient for growth of rillscale, although nitrogen was also implicated. Chemical limitations to the growth of rillscale on bentonite mine spoil generally appeared to be effects of toxicities or imbalances in elemental composition, or indicators of structural characteristics of spoil. This species appeared to be very sensitive to an increase in the level of spoil molybdenum and in the ratio of copper to molybdenum, but was tolerant of high levels of soluble salts and sodium.

\section{Literature Cited}

Allison, F.E. 1965. Decomposition of wood and bark sawdusts in soil, nitrogen requirements, and effects on plants. USDA-ARS. Tech. Bull. 1332.

Bannister, P. 1976. Physiological ecology and plant nutrition. p. 229-295. In:S.B. Chapman (ed.), Methods in plant ecology. John Wiley and Sons, New York.

Bjugstad, A.J., T. Yamamoto, and D.W. Uresk. 1981. Shrub establishment on coal and bentonite clay mine spoils. p. 104-122. In: Shrub establishment on disturbed arid and semi-arid lands. Symposium proceedings. Dec. 1980. Laramie, Wyo. Wyoming Fish and Game Dep., Cheyenne.

Brady, N.C. 1974. The nature and properties of soils. 8th ed. Macmillan Pub. Co. Inc., New York.

Bremner, J.M., and C.S. Mulvaney. 1982. Nitrogen-total. p. 595-624. In A.L. Page (ed), Methods of soil analysis. Part 2: Chemical and microbiological properties. 2nd ed. Monogr. 9 (Pt. 2) in the Agronomy Series. Amer. Soc. Agron. Inc., Madison, Wisc.

Buol, S.W., F.D. Hole, and R.J. McCracken. 1980. Soil genesis and classification. 2nd ed. Iowa State Univ. Press. Ames..

Carmer, S.G. 1976. Optimal significance levels for application of the least significant difference in crop performance trials. Crop Sci. 16:95-99.

Charley, J.L. 1977. Mineral cycling in rangeland ecosystems. p. 215-256. In: R.E. Sosebee (ed), Rangeland plant physiology. Soc. Range Manage. Denver, Colo.

Church, D.C., and W.G. Pond. 1978. Basic animal nutrition and feeding. Oxford Press, Portland, Ore.

Dollhopf, D.J., and B.J. Bauman. 1981. Bentonite mine land reclamation in the northern great plains. Montana Agr. Exp. Sta. Res. Rep. 179. Montana State Univ., Bozeman.

Epstein, E. 1972. Mineral nutrition of plants: Principles and perspectives. John Wiley and Sons Inc., New York.

Fassel, V.A., and R.N. Knisely. 1974. ICP-Optical emission spectroscopy. Anal. Chem. 46:1110A.

Frankton, C., and I.J. Bassett. 1970. The genus Ariplex (Chenopodiaceae) in Canada. II. Four native western annuals: A. argentea, A. truncata, A. powelli, and A. dioica. Can. J. Bot. 48:981-989.

Gestring, W.D., and P.N. Soltanpour. 1984. Evaluation of the ammonium bicarbonate-DTPA soil test for assessing boron availability to alfalfa. Soil Sci. Soc. Amer. J. 48:96-100.

Hayne, D.W. 1976. Experimental designs and statistical analyses in small mammal population studies. p. 3-13. In: Populations of small mammals under natural conditions. Pymatuning Laboratory of Ecology. Spec. Publ. Series Vol. 5. Univ. of Pittsburgh.

Havlin, J.L., and P.N. Soltanpour. 1980. A nitric acid plant tissue digest method for use with inductively coupled plasma spectrometry. Commun. Soil Sci. Plant Anal. 11:969-980.

Jones, J.B., Jr. 1977. Elemental a nalysis of soil extracts and plant tissue ash by plasma emission spectroscopy. Commun. Soil Sci. Plant Anal. 8:349-365.

La Haye, P.A., and E. Epstein. 1969. Salt tolerance by plants: enhancement with calcium. Science 166:395-396.

Larcher, W. 1980. Physiological plant ecology. 2nd ed. Springer-Verlag, New York.

Loneragan, J.F., and K. Snowball. 1969. Calcium requirements of plants. Aust. J. Agr. Res. 20:465-478.

Marshall, T.J., and J.W. Holmes. 1979. Soil physics. Cambridge Univ. Press, New York.

Mengel, K., and E.A. Kirkby. 1982. Principles of plant nutrition. 3rd ed. Internat. Potash Instit., Worblaufen-Bern, Switzerland. $655 \mathrm{p}$.

Murphy, L.S., and L.M. Walsh. 1972. Correction of micronutrient deficiencies with fertilizers. p. 347-387. In: J.J. Mortvedt, P.M. Giordano, and W.L. Lindsay (eds), Micronutrients in agriculture. Symp. Proc., April 1971. Muscle Shoals, Ala. Soil Sci. Soc. Amer. Inc., Madison, Wisc.

National Oceanic and Atmospheric Administration. 1983. Wyoming climatological data: Annual summary. Environmental Data and Information Center, Nat. Climatic Center, Asheville, N.C. 
Rhoades, J.D. 1982a. Soluble salts. p. 167-179. In: A.L. Page (ed), Methods of soil analysis. Part 2: Chemical and microbiological properties. 2nd ed Monograph No. 9 (Pt. 2) in the Agronomy Series. Amer. Soc. Agron. Madison, Wisc.

Rhoades, J.D. 1982b. Cation exchange capacity. p. 149-157. In: A.L. Page (ed), Methods of soil analysis. Part 2: Chemical and microbiological properties. 2nd ed. Monogr. 9 (Pt. 2) in the Agronomy Series. Amer. Soc. Agron. Madison, Wisc.

Sieg, C.H., D.W. Uresk, and R.M. Hansen. 1983. Plant-soil relationships on bentonite mine spoils and sagebrush-grassland in the northern High Plains. J. Range Manage. 37:289-294.

Smith, J.A. 1984. Wood residue and fertilizer amendments for reclamation of orphan bentonite mine spoils. M.S. Thesis. Univ. Wyoming, Laramie. Smith, J.A., G.E. Schuman, E.J. Depuit, and T.A. Sedbrook. 1985. Wood residue and fertilizer amendment of bentonite mine spoils: I spoil and general vegetation responses. J. Envir. Quality 14:575-580.

Soltanpour, P.N., A.E. Ludwick, and J.0. Reuss. 1979. Guide to fertilizer recommendations in Colorado. 2nd ed. Coop. Ext. Serv., Colorado State Univ., Fort Collins.
Soltanpour, P.N., and A.P. Schwab. 1977. Use of inductively coupled plasma spectrometry for the simultaneous determination of macro-and micronutrients in $\mathrm{NH}_{4} \mathrm{CO}_{3}$-DTPA extracts of soils. Soil Sci. Soc. Amer. J. 43:75-78.

Uresk, D.W., and T. Yamamoto. 1986. Growth of forbs, shrubs and trees on bentonite mine spoil under greenhouse conditions. J. Range Manage. 39:113-117.

Voorhees, M.E. 1990. Forage quality of rillscale (Atriplex suckleyi) grown on amended bentonite mine spoil. Great Basin Natur. 50:57-62.

Voorhees, M.E. M.J. Trlica, and D.W. Uresk. 1987. Growth of rillscale on bentonite mine spoil as influenced by amendments. J. Envir. Quality 16:411-416.

Voorhees, M.E. 1986. Infiltration rate of bentonite mine spoil as affected by amendments of gypsum, sawdust and inorganic fertilizer. Reclam. Reveg. Res. 5:483-490.

Voorhees, M.E., and D.W. Uresk. 1990. Effect of amendments on chemical properties of bentonite mine spoil. Soil Sci. 150:663-670. 